лізовані результати дослідження стійкості мікобактерій туберкульозу до протитуберкульозних препаратів у хворих на туберкульоз легенів, зареєстрованих у 2009-2010рр. по Харківській області. Аналіз показав несприятливу тенденцію збільшення сумарної частоти медикаментозної стійкості мікобактерій туберкульозу і ускладнення іï структури. Особливістю сучасної епідеміологічної ситуації по туберкульозу є зростання частоти первинної лікарської стійкості.

Ключові слова: туберкульоз, лікарська стійкість, епідеміологія.

\title{
PROFILES OF RESISTANCE OF ISOLATED STRAINS OF M.TUBERCULOSIS IN THE KHAR'KOV REGION
}

\section{O.S. Shevchenko}

Abstract. The object of this particular research was to evaluate a ratio between the sensitive and resistant strains of M.tuberculosis isolated from patients with an epidemiologically dangerous pulmonary form of tuberculosis. The results of studying the resistance of the mycobacteria of tuberculosis (MBT) to antituberculous preparations (ATP) have been analyzed in patients with pulmonary tuberculosis (TB) registered from 2009 to 2010 around the Khar'kov region. An analysis has demonstrated an unfavourable tendency of an increase of the total rate of medicamental resistance of MBT and making its amplification structure. A peculiar feature of the modern epidemiological situation connected with tuberculosis is a rise of the frequency of primary medicamental resistance.

Key words: tuberculosis, drug resistance, epidemiology.

National Medical University (Khar'kov)

Рецензент - проф. Л.Д. Тодоріко

Buk. Med. Herald. - 2013. - Vol. 17, № 2 (66). - P. 143-147

Надійшла до редакції 05.02.2013 року

(C) О.С. Шевченко, 2013

УДК 616.248+616.24-008:616-036.865 (477.44)

В.І. Шевчук, В.Ю. Забур'янова, М.В. Вернигородська

\section{СТРУКТУРА ТА РІВЕНЬ ІНВАЛІДНОСТІ ВНАСЛІДОК ХРОНІЧНОГО ОБСТРУКТИВНОГО ЗАХВОРЮВАННЯ ЛЕГЕНЬ І БРОНХІАЛЬНОӤ АСТМИ СЕРЕД ПРАЦЕЗДАТНОГО НАСЕЛЕННЯ ВІННИЦЬКОЇ ОБЛАСТІ}

Науково-дослідний інститут реабілітації інвалідів Вінницького національного медичного університету ім. М.І. Пирогова

Резюме. Вивчено структуру та рівень інвалідності внаслідок хронічного обструктивного захворювання легень (ХОЗЛ) та бронхіальної астми (БА) серед працездатного населення Вінницької області у 2011 році шляхом аналізу медико-експертної документації 692 осіб, у тому числі 208 інвалідів із ХОЗЛ та 484 інваліди 3 БА. Виявлено меншу тяжкість інвалідності і більш молодий вік осіб із БА порівняно із ХОЗЛ, що є перспе-

Вступ. Вивчення питань інвалідності внаслідок хронічних захворювань органів дихання, що супроводжуються бронхіальною обструкцією, має велике медичне, соціальне й економічне значення для суспільства, оскільки впливає на організацію і проведення медичних програм, направлених на профілактику i лікування цієї патології, та інвалідизацію населення, особливо в працездатному віці. Найбільш розповсюдженими $\epsilon$ хронічне обструктивне захворювання легень (ХОЗЛ) та бронхіальна астма (БА).

ХОЗЛ сьогодні - одна із найсерйозніших медико-соціальних проблем як у нашій країні, так і в усьому світі $[5,7]$. Її актуальність зумовлена перш за все надзвичайно високими показниками розповсюдженості, інвалідизації і смертності від цього захворювання, що зумовлено недостат- ктивним у плані реабілітації; значний відсоток осіб, інвалідність яким встановлюється пожиттєво; низькі показники реабілітації, особливо при ХОЗЛ, та необхідність розробки рекомендацій з медико-соціальної експертизи та реабілітації досліджуваного контингенту.

Ключові слова: інвалідність, хронічне обструктивне захворювання легень, бронхіальна астма.

ньою увагою до питань профілактики, несвоєчасною діагностикою і відсутністю адекватного лікування. За останні роки спостерігається лавиноподібне збільшення числа випадків ХОЗЛ. Пізнє його виявлення характерне не лише для України, але й для багатьох інших країн світу, у тому числі економічно розвинених, що пов'язано з майже безсимптомним перебігом захворювання на ранніх стадіях [5]. Бронхіальна астма також характеризується високими показниками захворюваності і смертності, значними економічними затратами для суспільства та індивідуума і суттєвим зниженням якості життя [4, 6].

Привертає увагу явна невідповідність розповсюдженості ХОЗЛ і астми їх рейтингових позицій у структурі первинної інвалідності [3], а та- 
кож значні відмінності показників первинної інвалідності у зв'язку із захворюваннями органів дихання на різних територіях [2]. Такі факти свідчать про низьку якість діагностики ХОЗЛ у лікувально-профілактичних закладах.

Показники первинної інвалідності внаслідок БА серед працездатного населення в Україні за 2009-2011 рр. були стабільними та склали в середньому 0,5 на 10000 населення, проте їх значні коливання спостерігались у різних регіонах, навіть у тих, які мають досить сприятливу кліматичну та економічну ситуацію [1].

Достовірна статистична інформація про інвалідність внаслідок ХОЗЛ в Україні, і зокрема у Вінницькій області, відсутня.

Мета дослідження. Вивчити та проаналізувати рівень і структуру інвалідності внаслідок ХОЗЛ та БА, а також причини та особливості формування контингенту інвалідів 3 даною патологією серед працездатного населення Вінницької області.

Матеріал і методи. Проведено поглиблене статистичне та соціально-гігієнічне дослідження медико-експертної документації вперше визнаних інвалідами (BBI) та повторно визнаних інвалідами (ПВІ) внаслідок ХОЗЛ та БА серед осіб працездатного віку в 2011 році у Вінницькій області.

Використані наступні методи дослідження: соціально-гігієнічний (метод документального обліку, методи математичної статистики), метод експертних оцінок, структурно-логічний аналіз.

Крім вибірки даних із медико-експертної документації, проведено аналіз державної статистичної звітності МСЕК.

Здійснено математичну обробку даних із розрахунками інтенсивних показників первинної, повторної та загальної інвалідності внаслідок ХОЗЛ та БА на 10000 населення в працездатному віці, екстенсивних показників розподілу інвалідності за віком, статтю та тяжкістю інвалідності. Для встановлення епідеміологічних особливостей інвалідності внаслідок ХОЗЛ та БА проводилося порівняння деяких їх аспектів.

Кількість ВВІ внаслідок ХОЗЛ та БА склала 66 осіб (ХОЗЛ - 25 осіб, БА - 41 особа), ПВІ 626 осіб (ХОЗЛ - 183 особи, БА - 443 особи). Всього 692 особи: ХОЗЛ - 208 і БА - 484 особи.

Результати дослідження та їх обговорення. Розподіл контингенту вперше визнаних інвалідами внаслідок ХОЗЛ та БА за віком і статтю свідчить про перевагу чоловіків (60,6\% чоловіків проти 39,4 \% жінок). Ця перевага зумовлена великою питомою вагою чоловічої статі серед інвалідів із ХОЗЛ (84,0 \% проти 16,0\%). У контингенті ж первинних інвалідів внаслідок БА дещо більше жінок (53,7 \%). Вік більшості ВВI внаслідок ХОЗЛ та БА (57,6 \%) складає 45-55 років, проте відзначається досить велика частка осіб до 40 років - 31,8 \%. При цьому кожний десятий у досліджуваному контингенті інвалідів не досяг і 30-річного віку. Наявність старших вікових груп більш характерна для ХОЗЛ: за даної патології питома вага осіб віком 45-55 років становить $68,0 \%$ і 56-60 років - 16,0 \%; у молодому віці таких інвалідів лише 16,0 \%. Інша картина спостерігається при БА: там інвалідів молодого віку майже половина - 46,4 \%, у тому числі $17,1 \%$ мають вік лише 18-29 років.

Рівень первинної інвалідності молодих інвалідів внаслідок ХОЗЛ низький і склав 0,07 на 10000 населення молодого віку; внаслідок БА - у 4,6 раза вищий $(0,32$ на 10000 населення відповідного віку).

Аналіз структури первинної інвалідності внаслідок ХОЗЛ та БА в осіб працездатного віку 3 урахуванням групи інвалідності вказує на те, що переважну більшість становлять інваліди 3-ї групи - 90,9 \%. Питома вага інвалідів 2-ї і 1-ї групи відповідно 7,6 \% та 1,5\%.

Привертає увагу значно більша тяжкість інвалідності при ХОЗЛ порівняно з БА, що узгоджується $з$ даними літератури. Так, у контингенті інвалідів внаслідок ХОЗЛ частка осіб із 3-ю групою інвалідності менша (відповідно 84,0 \% і 95,1 \%), 2-ї групи більша - у 2,4 раза (відповідно $12,0 \%$ і 4,9 \%), і є 4,0 \% інвалідів 1-ї групи (при БА інвалідність 1-ї групи не встановлювалася).

Рівень інвалідності 1-ї групи в контингенті BВI працездатного віку з ХОЗЛ та БА низький 0,01 на 10000 населення працездатного віку. Piвень інвалідності 2-ї групи вищий - 0,05 на 10000. Рівень інвалідності 3-ї групи є найвищим i складає 0,64 на 10000 відповідного населення.

Аналіз первинної інвалідності внаслідок ХОЗЛ та БА серед осіб працездатного віку показав, що основна причина - це загальне захворювання - становить 80,4 \%. Інваліди дитинства $12,1 \%$, інваліди армії, МВС, СБУ тощо - 4,5 \%; інваліди ЧАЕС - 3,0 \%. Найбільшу питому вагу становлять інваліди внаслідок загального захворювання в контингенті первинних інвалідів із ХОЗЛ - 96,0 \%; решту 4 \% становлять інваліди армії, МВС, СБУ. У контингенті ВВІ з БА частка інвалідів внаслідок загального захворювання менша - 70,7 \%; друге місце посідають інваліди дитинства - 19,5\%; інваліди армії, МВС, СБУ та інваліди ЧАЕС становили по 4,9%. Інвалідів внаслідок професійних захворювань не було.

Розподіл контингенту повторно визнаних інвалідами внаслідок ХОЗЛ та БА серед осіб працездатного віку за статтю у 2011 році свідчить про збільшення в ньому частки жінок порівняно 3 контингентом вперше визнаних інвалідами (відповідно 46,8 \% та 39,4 \%), причому це збільшення відбулось, в основному за рахунок жінок віком за 30 років. У віковій групі 18-29 років питома вага жінок у контингенті ПВІ внаслідок ХОЗЛ та БА порівняно незначна - 33,8 \%, проте вже в наступній віковій групі (30-39 років) вона збільшилася в 1,8 раза та становила 59,6 \%. Найбільшою вона була в осіб віком 40-44 роки $(60,7 \%)$, дещо зменшившись у найстаршій віковій групі (53,8 \%). I в контингенті ПВІ внаслідок 
ХОЗЛ, і в контингенті ПВІ внаслідок БА частка жінок зросла приблизно на 4 \%.

Найбільша кількість повторно визнаних інвалідів і при ХОЗЛ, і при БА має вік 45-55 років (відповідно 56,3 \% та 44,1 \%). Але якщо за першої нозології частка жінок цієї вікової групи у 2,5 раза менша, ніж частка чоловіків, то за другої - у 2,1 раза більша.

У структурі контингенту ПВІ внаслідок ХОЗЛ та БА привертає увагу більший, порівняно 3 контингентом BВI, відсоток чоловіків передпенсійного віку (12,0 \% проти 7,6 \%), а також велика питома вага таких осіб у контингенті інвалідів внаслідок ХОЗЛ порівняно 3 БА (відповідно $29,5 \%$ та $4,7 \%$ ).

Структура повторної інвалідності внаслідок ХОЗЛ та БА в осіб працездатного віку з урахуванням групи інвалідності свідчить про значне переважання питомої ваги інвалідів 3-ї групи, як і структура первинної інвалідності, проте відсоток таких інвалідів дещо менший (88,6 \% проти 90,9 \%), а інвалідів 2-ї групи - більший (10,9 \% проти 7,6 \%), тобто мова може йти про більш тяжку інвалідність ПВІ. Особливо це стосується контингенту повторно визнаних інвалідами внаслідок ХОЗЛ, у якому питома вага інвалідів 3-ї групи є меншою порівняно з BBI на 4,6 \%, а 2-ї групи більшою на 6,6 \%. При БА ці відмінності менш виражені (зменшується частка інвалідів 3-ї групи на 2,8 \% і на стільки ж збільшується частка інвалідів 2-ї групи).

Аналізуючи результати переогляду інвалідів працездатного віку внаслідок ХОЗЛ та БА у 2011 році, ми звернули увагу на вкрай низькі показники повної реабілітації: не визнано інвалідами лише 3,4 \% всіх осіб. Дещо більшим цей показник був в осіб з БА (3,7 \%), тоді як у контингенті інвалідів із ХОЗЛ він становив 2,7\%.

Під час переогляду інвалідів внаслідок ХОЗЛ особи 2-ї групи визнавались інвалідами цієї у 89,3 \% випадків та інвалідами 3-ї групи - у 10,7 \% (повної реабілітації не було). Особи 3-ї групи в 3,1 \% випадків інвалідами не визнані, у 89,4 \% - визнані інвалідами 2-ї групи і 1,9 \% інвалідами 1-ї групи. Тобто, повна реабілітація серед інвалідів 3-ї групи з ХОЗЛ становила 3,1%; обтяжувальність інвалідності спостерігалось у 7,5 \% інвалідів.

Переогляд інвалідів внаслідок БА 2-ї групи підтвердив 2-гу групу інвалідності 76,3\% осіб; 23,7 \% були частково реабілітовані (що у 2,2 раза більше, ніж при ХОЗЛ). 3 числа інвалідів 3-ї групи повністю реабілітовано 4,0 \%; 3-тя група залишилась на рівні 94,8 \%, і лише в 1,2 \% відзначалося збільшення тяжкості інвалідності (була встановлена 2-га група інвалідності).

Одна 3 основних причин інвалідності ПВІ при ХОЗЛ та БА - це інвалідність внаслідок загального захворювання, як і в контингенті ВВI (77,1 \%), проте для повторної інвалідності характерною є більша іï тяжкість: питома вага інвалідів 1-ї групи становить 0,6 \%, 2-ї групи - 11,2 \%, 3-ї групи - 88,2 \%. При цьому інвалідність 1-ї групи зумовлена лише наявністю інвалідів внаслідок ХОЗЛ; за даної патології частка інвалідів 2-ї групи становить 20,4 \%, що в 3,2 раза більше порівняно з БА. Привертає увагу збільшення в контингенті ПВІ внаслідок ХОЗЛ та БА питомої ваги інвалідів дитинства (19,0 \%); особливо великою вона виявилась серед хворих на БА $(26,0$ \%). Тобто, кожний четвертий інвалід внаслідок БА визнаний інвалідом дитинства, причому тяжку інвалідність має кожний десятий 3 них. Незначну питому вагу в структурі причин інвалідності осіб працездатного віку з ХОЗЛ та БА, повторно визнаних інвалідами, посідають інваліди армії, МВС, СБУ тощо - $1,9 \%$; інваліди ЧАЕС - 0,2 \%; інші причини (професійні захворювання) становлять $1,8 \%$.

Проведене дослідження показало, що у 2011 році у Вінницькій області при первинному огляді визнано інвалідами внаслідок ХОЗЛ та БА пожиттєво 7,6 \% ВВІ: серед інвалідів із ХОЗЛ частка таких осіб становила 8,0 \% і серед інвалідів 3 БА - 7,3\%. При повторному огляді визнано інвалідами пожиттєво 16,6 \% ПВІ: серед інвалідів із ХОЗЛ - 18,6 \% і серед інвалідів із БА - 15,8\%. Тобто, майже кожний шостий повторно визнаний інвалід внаслідок ХОЗЛ чи БА, перебуваючи в працездатному віці, продовжує отримувати від держави пенсію у зв'язку з інвалідністю без повторного огляду на МСЕК і випадає з поля зору працівників МСЕК у плані його подальшої реабілітації.

\section{Висновки}

1. У структурі первинної та повторної інвалідності внаслідок хронічного обструктивного захворювання легень та бронхіальної астми спостерігається перевага чоловіків за рахунок інвалідів iз хронічним обструктивним захворюванням легень, серед яких більшість складають особи віком понад 45 років. При бронхіальній астмі контингент інвалідів молодший (кожний шостий - віком до 30 років), з меншою тяжкістю інвалідності, i може бути перспективним у плані реабілітації.

2. Однією з основних причин інвалідності внаслідок хронічного обструктивного захворювання легень та бронхіальної астми серед працездатного населення є загальне захворювання. При бронхіальній астмі важливе значення має інвалідність 3 дитинства, притаманна чверті осіб.

Перспективи подальших розробок. Аналіз показників реабілітації інвалідів внаслідок ХОЗЛ та БА свідчить про недостатність заходів, які впливають на цей процес та необхідність розробки науково-обгрунтованих рекомендацій з медико-соціальної експертизи і реабілітації даного контингенту.

\section{Лiтература}

1. Основні показники інвалідності та діяльності медикосоціальних експертних комісій України за 2011 рік: Аналітико-інформаційний довідник. - Дніпропетровськ, 2012. 
2. Пьянкова И.В. Социально-гигиенические аспекты инвалидности, медико-социальная экспертиза и реабилитация при болезнях органов дыхания: автореф. дис. на соискание уч. ст. к. мед. н.: 14.00 .00 / И.В. Пьянкова; И.В. Федер. Бюро мед.-социал. экспертизы. - М., 2007. $27 \mathrm{c}$.

3. Рейтинг и структура первичной инвалидности при болезнях органов дыхания в Краснодарском крае / С.А. Павлищук, Е.В. Боготова, Т.В. Терещенко [и др.] // Медикосоциальная экспертиза и реабилитация. - 2005. - № 1. C. $32-35$

4. Фещенко Ю.И. Достижения контроля - современная стратегия ведения бронхиальной астмы / Ю.И. Фещенко // Астма та алергія. - 2007. - № 1-2. - С. 5-9.
5. Фещенко Ю.И. Хроническое обструктивное заболевание легких - актуальная медико-социальная проблема / Ю.И. Фещенко // Укр. пульмонол. ж. - 2011. № 2. - C. 6 .

6. Global Initiative for Asthma. Global Strategy for Asthma Management and Prevention. Workshop Report, 2009. http: // www.ginasthma.com.

7. Global Strategy for the Diagnosis, Management and Prevention of Chronic Obstructive Pulmonary Disease (Updated 2009) [Електронний pecypc] // CMedical Communications Resources, Inc - 2009 - режим доступу: http://www.goldcopd.com/ Guidelineitem.asp? $11=2 \& 12=1 \&$ intld $=989$.

\section{СТРУКТУРА И УРОВЕНЬ ИНВАЛИДНОСТИ ВСЛЕДСТВИЕ ХРОНИЧЕСКОГО \\ ОБСТРУКТИВНОГО ЗАБОЛЕВАНИЯ ЛЕГКИХ И БРОНХИАЛЬНОЙ АСТМЫ СРЕДИ РАБОТОСПОСОБНОГО НАСЕЛЕНИЯ ВИННИЦКОЙ ОБЛАСТИ}

\section{В.И. Шевчук, В.Ю. Забурьянова, М.В. Вернигородская}

Резюме. Изучена структура и уровень инвалидности вследствие хронического обструктивного заболевания легких (ХОЗЛ) и бронхиальной астмы (БА) среди работоспособного населения Винницкой области в 2011 году путем анализа медико-экспертной документации 692 чел., в том числе 208 инвалидов с ХОЗЛ и 484 инвалидов с БА. Выявлено меньшую тяжесть инвалидности и более молодой возраст лиц с БА по сравнению с ХОЗЛ, является перспективным в плане реабилитации; значительный процент лиц, инвалидность которым устанавливается пожизненно; низкие показатели реабилитации, особенно при ХОЗЛ и необходимость разработки рекомендаций по медико-социальной экспертизе и реабилитации изучаемого контингента.

Ключевые слова: инвалидность, хроническое обструктивное заболевание легких, бронхиальная астма.

\section{THE STRUCTURE AND LEVEL OF DISABILITY DUE TO CHRONIC OBSTRUCTIVE PULMONARY DISEASE AND ASTHMA AMONG THE WORKING POPULATION IN THE VINNYTSIA REGION}

\section{V.I. Shevchuk, V.Yu. Zaburyanova, M.V. Vernyhorodska}

Abstract. The structure and level of disability due to chronic obstructive pulmonary disease (COPD) and bronchial asthma (BA) among the working population in the Vinnytsia region in 2011 by reviewing the medical expert documentation of 692 people including 208 disabled people with COPD and 484 disabled people with asthma were studied. A lesser severity of disability and a younger age of people with BA as compared with COPD has been revealed, it is promising in terms of rehabilitation; a significant percentage of people whose disability is established for life; low indices of rehabilitation, particularly in COPD, and the necessity to elaborate recommendations on the medicosocial examination and rehabilitation of the contingent under study.

Key words: disability, chronicoobstructive pulmonary diseases, bronchial asthma.

Рецензент - проф. Л.Д. Тодоріко
Buk. Med. Herald. - 2013. - Vol. 17, № 2 (66). - P. 147-150

Надійшла до редакції 07.03.2013 року

(С В.І. Шевчук, В.Ю. Забур'янова, М.В. Вернигородська, 2013 